\title{
Branding as an identification of the territory potential: insufficiency of
}

\author{
constructivist approach \\ Tatiana Bystrova ${ }^{\mathrm{a}^{*}}$, Dmitry Kochetkov ${ }^{a b}$ \\ ${ }^{a}$ Ural Federal University, Russia \\ ${ }^{\mathrm{b}}$ Institute of Economics, Ural Branch of the Russian Academy of Sciences, Russia \\ *Corresponding author: Tatiana Bystrova, Doctor of Sciences, Professor, taby27@yandex.ru
}

\begin{abstract}
Since the 2000s, branding of cities and territories has attracted greater attention of scientists and practitioners in developed and emerging countries. The results of our study can be divided into two parts, theoretical and practical. First, we derived the theoretical and methodological foundations of urban branding grounding both on theoretical assumptions and empirical Russian material. Then, we described approbation of the project approach. The empirical material supported the hypothesis that the living brand cannot be designed and implemented by external coercion: it is already existing in hidden form in the territory.
\end{abstract}

Key words: brand, urban branding, place branding, city branding, phenomenology of the brand, culture of participation, Russia

\section{Introduction}

Since 2000, city branding has become a "must” for developed countries in the West ${ }^{1-4}$ and in the East, e.g. Singapore, Shanghai ${ }^{5-8}$. This increase was fuelled by the growing competition between cities ${ }^{9}$, increasing mobility of capital and human resources ${ }^{10}$, and European integration ${ }^{11}$. Nevertheless, a number of researchers emphasize the gap between the theory and practice of urban branding ${ }^{12,13}$. City branding attracts the attention of scientists and practitioners in Russia as well. However, theoretical papers on this problem can be counted on the fingers ${ }^{14-16}$; most of the scientific publications are case studies ${ }^{17-20}$.

In theory, branding (including place branding) is understood as an activity to create additional intangible characteristics of a product or service that gives it greater appeal in the eyes of consumers or investors, and hence, increasing its competitiveness. Only a few examine the target audience and define the brand as a "strategic cultural idea", i.e. an idea that is not 
separable from its bearers. But they also prefer to design the brand in accordance with the expectations of consumers, without extracting the brand value from the place itself.

Due to the ambiguity of the grounds of the place brand, its characteristics are mutating beyond recognition in practice. The brand is confused with its carriers (e.g. the expression "branding of the product", used by Russian designers and advertising specialists when printing a logo on its surface). Not quite competent experts arbitrarily allocate a place or an object with the random values. When looking for unique brand features, they often find it necessary to create them on their own, i.e. "construct". Whereas the idea of branding implies the identification, gradual formation of the uniqueness of a product or territory due to the uniqueness of communications and culture.

In the process of design, the communicative goal of creating a brand has been completely forgotten, its formation takes on the character of a ritual, a self-sufficient formalized action, because it is necessary to create a visual confirmation of the characteristics of the place that did not exist before the start of the works on branding. Thus, we fix the opposition of constructivist $^{21}$ and phenomenological approaches in the place branding. Adhering to the second of them, we will show the inadequacy of the constructivist approach.

\section{Methodology}

The results can be divided into two parts, theoretical and practical. In the first part, we derived the theoretical and methodological foundations of city branding, based both on theoretical assumptions and empirical Russian material. The phenomenological method makes it possible to study the subjective and semantic aspect of human existence, and to reveal the structuredness of the vital world.

In the practical part, we described an approbation of the project approach, which has a participative character ${ }^{22}$. The project becomes a dynamic open system with a certain degree of unpredictability in development, since much of its implementation depends on the actions of the involved participants.

\section{Results and discussion}

Place branding is most often associated with activities for positioning the territory. Note that since the early 1990s, three approaches to positioning have been existing in Russian practice. 


\subsection{Place branding in comparison with place marketing and image building}

Followers of the place marketing focus on its economic goals and activities of economic agents. Specialists in the image of the territory ${ }^{23-25}$ form an attractive image, often employing the design of the visual properties of this image, especially in the areas that are not sufficiently developed. The Russian branding is dominated by the constructivist approach, the allocation of arbitrary, standard, or narrowly specialized properties ("the capital of Ded Moroz" (Russian figure akin to Santa Claus in the West) - Veliky Ustyug, "the third capital" Kazan, Ekaterinburg, Novosibirsk, "tea capital" - Kungur, "city of mice" - Myshkin (Russian “myshka” stands for English “mouse”).

In a number of cases, such as Ashworth \& Kavaratzis (2010), Sherrington (2003), at the wording level, all strategies are mixed into a single activity, which is difficult to conceptualize and pass on to other specialists, though being successful.

It is essential that the brand as an element of communication has an axiological nature ${ }^{28}$. This means that it cannot be reduced to a set of physical characteristics. The brand is the result of a certain discourse, a certain optics, i.e. an evaluative view of the subject in terms of the territory, and a comparison of this impression with the value scale and the needs of people. If people do not imagine what they value, it is useless to show them anything in the guise of a brand (a good example of this is the long-standing attempts of specialists to draw attention of the public of Ekaterinburg to the objects of constructivist architecture that people consider "inexpressive"). And vice versa, while creating the brand, one cannot ignore the needs and values of his audience or ascribe to it irrelevant or non-existent desires.

Under the influence of the ideas of the "city for pedestrians" ${ }^{29}$, creative class ${ }^{30}$, creative city ${ }^{31}$, the real development of the culture of participation in cities, the theory and practice of place branding is developing. Thus, K. Dinnie ${ }^{32}$ indicate that place branding today is oriented, mainly, not so much to tourists as to "the enthusiasm of local residents" grounding on the idea of including in the project a variety of stakeholders. It is necessary to ask each group about the values of the brand and provide their engagement.

\subsection{Evolution of the value approach and its projection on the place branding}

Value is a concept with a long history, which has become common in general usage relatively recently, and has a variety of interpretations. At first glance, it seems almost transparent to everyday consciousness. In fact, the transition to value discourse entails significant consequences in the attitudes of researchers or designers. 
According to I. Kant ${ }^{33}$, evaluating something with the help of a "reflective" judgment ability, a person experiences a feeling of pleasure or displeasure, correlating the individual (information about the object) not with the idea already known to him, but with the one that is to be found. For this, there is insufficient intelligence and reason, with which European rationalism is so proud and shining.

Friedrich Nietzsche also paid attention to the ability of judgment developing and overcoming the Kantian (classical rationalist) interpretation of the subject (actor) as an active, intelligent, and goal-oriented creature. He considered evaluation to be the most important mode of human life: a person refers to everything that is around him, and, thereby, knows himself better. In the process of evaluation, it is not so much subjectivity as independence that is important.

According to F. Nietzsche ${ }^{34}$, the attitude to something as a value:

- Deprives the leading position of the rational principle in human, returning to him the unity of body and spirit, the emotional and rational;

- Subjunctivizes this attitude, takes it away from general impersonal judgments, i.e. when evaluating, the person is hearing to himself willing or not;

- In some cases, a search for value gives a person the right to his own, individual position.

Saying the word "value", we are moving away from opposing a person to what he values. Unlike scientific observation, this process requires the work of emotions and imagination. Phenomena that have not been evaluated look as if they did not at all exist in the living space, even if they influence the person.

According to M. Weber ${ }^{35}$, values are something that allows a person to better understand and formulate their goals. Being the ancestor of "understanding sociology," Weber emphasizes that a sociologist can predict their social behavior, choice, lifestyle, etc. by isolating the value system of people of a certain type. At the same time, an emphasis is put on the qualitative characteristics of the audiences allocated according to the type of dominant values. The individual realizes values, more precisely, he chooses them from the sociocultural context that is synchronized with him and, therefore, can be isolated in the course of inquiries or interviews, or just recorded by the actions of a person.

Domination of the value-semantic component, present in the cultural space of the territory, ensures the adequacy of the brand. If this value is brought from outside, the brand will not have content. The following example is illustrative. Having visited Yekaterinburg in May 2011, the chief architect of Barcelona, Josep A. Acebillo Marin, as they say, "on the spur of the moment", spoke about the importance and picturesqueness of the city's location between 
the three water reservoirs. He did not take into account the specifics of our traditional Ural assessment: a reservoir, especially a pond, is something that should help to survive and work in harsh natural and climatic conditions. The pond arises where the dam is built, which is a city-forming structure for the Urals city-plants. It is not created to enhance the beauty of the landscape; its purpose is purely industrial. It is the industrial component that makes the Ural cities unique. To abandon it for the sake of decorativeness means to forget our own history.

\subsection{Characteristics of place brand}

The brand can be oriented to the embodiment of values and the image of the future. At the same time, a certain realism of the developers' position is needed: they clearly recognize the original properties of the territory, exclude fantasy projects. (Here we can recall the division of fantasy and the "day dream" of the founder of the philosophy of hope, the German philosopher Ernst Bloch. The "day dream" (Tagtraum) is effective and efficient because it "grows out of the present"

The relationship between the initial characteristics of the territory and residents is well manifested in the branding of everyday culture. In response to globalization, elements of everyday culture, not widely recognized sights, can become valuable for tourists. They need to be "discovered"; it is essential to give more concentrated and extensive information about them ${ }^{25,37}$; perhaps, to strengthen information support, i.e. myth, history, comments, etc. Values at the level of "masterpieces" today are not always interesting to people who have long studied them on the Internet. They are very far from living experience and real context. Contact with everyday artifacts and practices (an unusual house, fragments of an eclectic urban environment, graffiti and street art, communities of skateboarders, bicyclists, kitingers, etc.) give new emotions and unusual feelings, which become part of a person's memory or biography. These initial fragments of the brand can be found both in history and modern times. Thus, we create the ground for a bright living brand by institutionalizing such elements or simply by drawing attention to them, by increasing the degree of engagement of the residents or guests of the place.

An example of this approach is the "onion festival" in the village of Lukh, Ivanovo region. The name of the place, which arose in 1404, is consonant with the name of the popular vegetable, which played a big role in the culture of Russia. The onion festival takes place at the end of summer in a village that has preserved its historical appearance. It attracts tourists with the opportunity to get acquainted with songs, crafts, folk speech, to get in touch with the 
culture of the Russian province. The holiday does not have an official formal component, its scale is relatively small (5 thousand people in 2016). The unique coincidence of the location in the center of Russia, the name, history, current state does not require additional constructivist actions. The holiday "grows" from the way of life and occupations of the inhabitants of the village. It is natural, and it attracts and inspires people. In St. Petersburg, professional art is part of the everyday urban culture; it is quite appropriate to talk about the art market as one of the foundations of the brand - not because that's what someone decided, but because it happened historically ${ }^{38}$.

With this approach, the work on creating a brand of the place is more adequately pronounced in terms of "disclosure of potential" than "giving meaning." The importance of stakeholders, especially residents, needs to be calculated especially considering the effect of long-term loyalty to the territory on the part of those who participated in the process of its "disclosure". The value of the place brand should meet a number of other requirements, in our opinion. We list them.

- The brand is not an end in itself or a separate independent product, torn from the system of other means of place promotion. Its values cannot come into conflict with the dominant values of the audience.

- The authenticity of values, their verifiability, and confirmability requires the rejection of the mythologization so actively practiced today at the Russian regional level. It is necessary to achieve a certain uniqueness, recognition in their visualization; to objectify values in souvenirs. Moreover, it is essential to work out scenarios of "contact" with values.

- The prospects for the brand existence are determined by the connection of its values not so much with the past (as is often the case in modern branding practices of Russian regions), but mainly with the future. A brand is something that is mastered and broadcast by people of different generations. It leads to their activation in relation to the territory. Knowledge of the past is necessary from the point of view of keeping the social memory, maintaining spirituality, which should not be identified with branding procedures.

Our brand characteristics were tested in the participatory interactive exhibition "What did the city tell me?", which was moderated by T. Bystrova. 


\subsection{The project "What did the city tell me?" in the system of branding activities of}

\section{Ekaterinburg}

A good brand will flourish even with a small budget.A weak one will not survive even with huge funding.

(From the specialists' talk)

The initial methodological settings were approved by the authors during the implementation of the project "What did the city tell me?" (2.04.-15.06.2017, Ekaterinburg Academy of Contemporary Art, about 45 participants). The basis of the project was the idea of collective reading of the city as hypertext, and participants were the students of Ekaterinburg universities.

At the first stage, the students just photographed the city according to a semiotic setting to read any signs and codes as a single hypertext. The most difficult was the answer to the question "What did the city tell me?", which was to become the signature under the photograph. Most often, the project participants arbitrarily referred to an architectural object or plot, not allowing the place to "babble out". However, the conditions of the competition were such that the replica-signature should come from the city as a subject of communication. At the second stage, after the opening of the exhibition, all visitors were engaged in "reading". They were invited to make captions under photographs focusing on the content of photos, their status, associative roll calls of the text of the city of Ekaterinburg with other texts of culture, quotations, proverbs, etc. Thus, the city, whose importance is often underestimated by the inhabitants, was part of a broader cultural space. Its everyday life became an occasion for emotional experience and evaluation.

It is noteworthy that during the exhibition new participants joined it. They brought and sent photos after the opening.

At the final stage, the most original photos and signatures were chosen by means of a spectators' vote. They became the basis of the calendar, which was designed by one of the students of the Ekaterinburg Academy of Modern Art in the framework of the bachelor's degree work. Her product, exhibited in several museums in Ekaterinburg, will help in the further spread of the non-standard vision of the city, its reassessment. Such actions contribute to the isolation of significant characteristics of the place and its branding.

\section{Conclusions}

This study proved the importance of the phenomenological definition of the brand of the territory, the values of which are not constructed arbitrarily. They are identified by specialists 
in the process of studying the way of life and everyday culture of the place. Accordingly, a number of critical remarks have been made about the constructivist approach to the place branding, which gravitates toward the allocation of places with arbitrary values, which has a short-term effect and requires large investment infusions.

The hypothesis has been supported: the living brand engendering active communications with the territory cannot be designed and implemented by external coercion, it already exists in hidden form in the territory. The task of specialists is to identify and strengthen it. This task is gradually solved in the course of participatory projects.

\section{Acknowledgements}

The authors wish to thank Russian Foundation for Basic Research for financial support of this research (project 17-22-07001 “The complex algorithm of culture-based regeneration of old industrial cities”). This work was also supported in part by Act 211 of Government of the Russian Federation, contract № 02.A03.21.0006.

\section{References}

1. K. Dinnie, City Branding: Theory and Cases. Palgrave Macmillan, 2011.

2. J. de San Eugenio Vela, The relationship between place branding and environmental communication: The symbolic management of places through the use of brands, Place Brand Public Dipl. 9 (2013) 254-63.

3. M. Giovanardi, A. Lucarelli, C. Pasquinelli, Towards brand ecology: An analytical semiotic framework for interpreting the emergence of place brands, Mark Theory. 13 (2013) 365-83.

4. S. Brown, A. Campelo, Do cities have broad shoulders? Does Motown need a haircuit? On urban branding and the personification of place, J Macromarketing 34 (2014) 421434.

5. T.C. Chang, Renaissance revisited: Singapore as a "global city for the arts." Int J Urban Reg Res, 24 (2000) 818-31.

6. L. Kong, Cultural icons and urban development in Asia: Economic imperative, national identity, and global city status. Polit Geogr. 26 (2007) 383-404.

7. C-S. Ooi, Reimagining Singapore as a creative nation: The politics of place branding, Place Brand Public Dipl. 4 (2008) 287-302. 
8. N. Dynon, Better city, better life? The ethics of branding the model city at the 2010 Shanghai world expo, Place Brand Public Dipl. 7 (2011) 185-96.

9. M. Boisen, K. Terlouw, B. van Gorp, The selective nature of place branding and the layering of spatial identities, J Place Manag Dev. 4 (2011) 135-47.

10. M. Kavaratzis, G. Warnaby, G.J. Ashworth, editors. The need to rethink place branding. In: Rethinking Place Branding. Springer, 2015. p. 1-11.

11. M. Kavaratzis, G.J. Ashworth, City branding: An effective assertion of identity or a transitory marketing trick? Tijdschr voor Econ en Soc Geogr. 96 (2005) 506-514.

12. M. Kavaratzis, Place branding scholars and practitioners: "Strangers in the night”? J Place Manag Dev. 8 (2015) 266-70.

13. A. Green, D. Grace, H. Perkins, City branding research and practice: An integrative review. J Brand Manag. 23 (2016) 252-72.

14. E.Y. Burlina, Y.A. Kuzovenkova, I.A. Golubinov, City plus Image: Theory, sociocultural training, regional projects. Samara State Medical University, Samara, 2010.

15. A. Ovrutskii, Urban style in the context of consumption, Urban Stud. 3 (2016) 1-10.

16. V.V. Kulibanova, T.R. Teor, Innovative place branding tools: definition, essence, implementation mechanism, St Petersbg State Polytech Univ Journal Econ. 256 (2017) $122-9$.

17. G. Merzlyakova, L. Batalova, Okonnikova T. Historical and cultural bases of formation of the tourist brand «Izhevsk - the forging arms capital of Russia», Serv Tour Curr Challenges. 8 (2014) 44-54.

18. M. Semenov, Revealing identity of Saint Petersburg: research and competition, Archit Proc High Educ. 52 (2015) 14.

19. A. Balashov, A.Sanina, Strategic orientations in the development of St. Petersburg: contradictions between the declared values and the existing practice of local government, J Soc Policy Stud. 14 (2016) 197-212.

20. N. Obnorskaya, Merchants history as a component of tourism brand of historical city (the case of Yaroslavl), Serv Russ abroad. 10 (2016) 54-66.

21. F.G. Wallner, F. Lan, A. Schulz, editors. Aspekte des Konstruktiven Realismus (= Culture and Knowledge 21). Peter Lang, Frankfurt am Main, 2012.

22. C. Alexander, S. Ishikawa, M. Silverstein, A Pattern Language: Towns, Buildings, Construction. OUP USA, New York, 1977. 
23. K. Lynch, The Image of the City. MIT Press, Cambridge, London, 1960.

24. I.S. Vazhenina, Territory in the system of economic relations. Institute of Economics, Ural Branch of RAS, Ekaterinburg, 2008.

25. G.G. Pocheptsov, Image. REFL-book, Moscow, 2004.

26. G. Ashworth, M. Kavaratzis, Towards Effective Place Brand Management: Branding European Cities and Regions. Edward Elgar Publishing Limited,Cheltenham, Northampton, 2010.

27. M. Sherrington, Added Value: The Alchemy of Brand-Led Growth. Palgrave Macmillan UK, 2003.

28. J. Grant, Brand Innovation Manifesto: How to Build Brands, Redefine Markets and Defy Conventions. Wiley, 2011.

29. J. Jacobs, The Death and Life of Great American Cities. Knopf Doubleday Publishing Group, 2016.

30. R. Florida, Who's Your City?: How the Creative Economy Is Making Where to Live the Most Important Decision of Your Life. Basic Books, Random House, 2008.

31. C. Landry, The Creative City: A Toolkit for Urban Innovators. Comedia/Earthscan, London, Sterling, 2012.

32. K. Dinnie, Introduction to the theory of city branding. In: City Branding: Theory and Cases. Palgrave Macmillan, Basingstoke, Hampshire, 2011.

33. I. Kant, Kritik der Urteilskraft. Tredition, Hamburg, 2012.

34. A.S. Turpetko, Axiology beyond metaphysics: F. Nietzsche through the eyes of M. Heidegger, Uchenye Zapiski Tavricheskogo Natsionalnogo Universiteta im. V I. Vernadskii Series "Philosophy. Culturology. Political science. Sociology” 26 (2013) 71-78.

35. M. Weber, The Meaning of value Freedom in the Sociological and Economic Sciences. In: H.H. Bruun, S. Whimster, editors. Max Weber: Collected Methodological Writings. Routledge, London and New York, 2012. p. 304-34.

36. E. Bloch, Das Prinzip Hoffnung: in fünf Teilen. Suhrkamp, 1985.

37. T. Bystrova, Human reason of the liquid modernity era: rethinking of the Abhidharma concept. In: The 5th International Conference on Comparative Studies of Mind (ICCSM). Chung-Ang University, Seoul, 2014. p. 85-93.

38. V. Pashkus, N. Pashkus, M. Pashkus, The formation of a culturally robust brand of the city of St. Petersburg. Reg Econ Theory Pract. 22016 39-53. 